\title{
DETECTION OF ENTEROVIRUSES IN CASES OF NEUROLOGICAL DISORDERS IN THE STATE OF PARÁ, BRAZIL
}

\author{
Maria de Lourdes Contente GOMES(1), Helena KOPECKA(2) \& Alexandre da Costa LINHARES(1)
}

\begin{abstract}
SUMMARY
Eighty-one cerebrospinal fluid (CSF) samples mainly from cases of aseptic meningitis and motor deficiency syndrome were sent to the Virology Section of Evandro Chagas Institute, Belém Pará, in the period of January 1995 to January 1996 in order to isolate viruses. All samples were inoculated onto HEp-2 cell culture and newborn mice, with negative results. The probability of isolating viruses by these methods is reduced because of the low concentration of viral particles in these specimens. In order to obtain more information about the etiology of these cases, a group of 23 samples were selected to be tested by a more sensitive technique than the virus isolation - the reverse transcription polymerase chain reaction (RT-PCR). Specific primers directed to conserved regions in the enterovirus genome were used, considering that this group of viruses is frequently associated with these neurological disorder. The age of the patients ranged from 1 to 55 years and nearly all of them lived in Belém, State of Pará, North of Brazil. Of 15 samples analyzed by RT PCR nine (60\%) were positive; of these, $6(66.6 \%)$ had motor deficiency and $3(33.3 \%)$ developed aseptic meningitis. These results show that it is important to investigate enterovirus as cause of these syndromes.
\end{abstract}

KEYWORDS: Aseptic meningitis; GBS; Enteroviruses

\section{INTRODUCTION}

Enteroviruses comprise a major subgroup of the family Picornaviridae and include the polio (3 serotypes), coxsackie A (23 serotypes), coxsackie B (6 serotypes), echoviruses (31 serotypes) and enterovirus $68-72^{2}$.

Infections with the Enteroviruses - even the more virulent members of the genus - are characterized by a high proportion of subclinical infections. The clinical manifestations when they occur, range from severe and permanent paralysis, sometimes fatal, to minor undifferentiated febrile illnesses. Clinical syndromes such as poliomyelitis, meningitis, pleurodynia, herpangina, hand-foot and mouth disease, respiratory illnesses, eye disease, cardiac diseases, neonatal disease, gastrointestinal diseases are frequently associated with the enteroviruse ${ }^{10}$.

With the virtual elimination of poliomyelitis, Guillain- Barré Syndrome (GBS) has become the most common cause of acute generalized paralysis with an annual incidence of 0.75 to 2 cases per 100,000 population $^{12}$. The association of enteroviruses with GBS was reported by URANO et al. ${ }^{17}$, in 1970, who, analyzing stool samples and cerebrospinal fluid from a $5^{1 / 2}$ year-old Japanese girl, detected Echovirus type 7. During 1990 to 1991, through a national surveillance poliomyelitis program, the Ministry of Health of Paraguay received reports of 50 children with incident acute flaccid paralysis $(<15$ years old $)$. Of these, 37 were diagnosed as having GBS. Nineteen children had stool culture that tested positive for enteroviruses. Of these, 4 were echovirus, 1 excreted vaccinal poliovirus and 14 shed unidentified nonpolio enterovirus ${ }^{6}$.

Unlike of GBS, aseptic meningitis (AM) is often related to Enteroviruses (EV). Besides polioviruses, several echovirus serotypes, and almost all coxsackievirus of both A and B groups have been associated with the disease. In the sixties the occurrence of an outbreak of AM due to echo 4 and an epidemic of meningitis caused by echo type 6 were reported by HININA et al. and HANNINEN and POLIJONEN, respectively ${ }^{2}$. In 1975, MARIER et al. reported an outbreak of AM among neonates, associated with Coxsackievirus B5 ${ }^{9}$. In the beginning of the 80's years, JARVIS \& TUCKER ${ }^{7}$ reported one case of meningitis in a young children due to Echo type 7. One localized outbreak of enteroviral meningitis in adults occurred in Finland, in 1985, as described by KINNUNEN et al. ${ }^{8}$ They examined 21 ill young adults and EV-positivity was found in $80 \%$. Studies conducted by BERLIN et al. ${ }^{1}$ in 274 children $<24$ months old, attending three hospitals in Baltimore (USA), between 1st July, 1986 and 31 December, 1990, have shown that group B coxsackieviruses and echoviruses were implicated in 156 (92\%) of the 169 laboratory diagnosed cases. It is important to mention that in all of these studies the standard virologic methods were used.

(1) Seção de Virologia do Instituto Evandro Chagas, FUNASA, Belém, PA, Brasil.

(2) Molecular Virology Unit, Pasteur Institute, Paris, France.

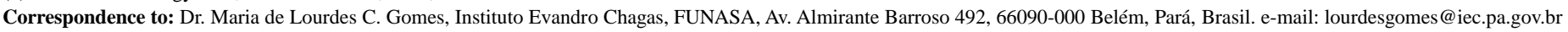


In the past decade, the number of studies of AM associated with EV increased considerably, due to the use of molecular technique applied to the detection of the viral nucleic acid. In order to study the enzymatic RNA amplification, ROTBART ${ }^{13}$ selected 20 CSF samples from 20 different children with AM (12 cases) encephalitis (1 case) Haemophilus influenzae type B meningitis (4 cases) and miscelaneous (3 cases). Of the 12 children with AM, all had PCR - positive results. Enteroviral RNA was also detected in the single patient with encephalitis. The others were negative. THORÉN \& WIDELL ${ }^{16}$, studying CSF and serum specimens from 27 consecutive patients with AM, detected enterovirus RNA in 15 CSF samples by PCR. Acute-phase sera proved positive for enterovirus RNA in 11 patients. Convalescent-phase sera were all negative by PCR. These authors also used the conventional virological procedures and found a correlation of $78 \%$ between them.

In Brazil, studies dealing with EV in the etiology of cases of GBS are lacking whereas those related to AM are scarce. GODOY et al. ${ }^{4}$ analyzed 40 clinical cases of AM, all hospitalized in "Hospital de Isolamento Emilio Ribas" (São Paulo), during the first semester of 1964. In $10(25 \%)$ cases poliovirus was detected. One of these patients was excreting Polio 2 and Coxsackie A13. The remaining cases were negative. More recently, TAKIMOTO et al. ${ }^{15}$ reported a study including $138 \mathrm{AM}$ patients with the ages ranging from 4 months to 57 years, attending several hospitals in São Paulo State. A probable new agent was isolated from the cerebrospinal fluid of 35 of 53 specimens examined. Replication of an agent with similar CPE (cytopathogenic effect) characteristics in MDCK cells was detected. Virus-like particles measuring about $40 \mathrm{~nm}$ in diameter were observed by negative staining electron microscopy.

The aim of this study is to investigate the etiology of cases of AM and motor deficiency in the state of Pará, Northern Brazil.

\section{MATERIAL AND METHODS}

Patients: Cerebrospinal fluid (CSF) samples from 81 cases of motor deficiency (paresis of the lower limbs, GBS) and AM were received in the Virology Section of Evandro Chagas Institute, in the period of January/95 to January/96. Of these, 15 were submitted to the RT-PCR test ( 9 from patients with motor deficiency, 6 from patients with AM). The ages of patients ranged from 1 to 55 years ( 9 were female and 6 were male). They lived in Belém and other cities of the state of Pará, Northern Brazil.

Routine laboratory procedures: In order to isolate viruses, all 81 samples were inoculated onto tissue culture and newborn mice. Each sample was inoculated directly into two tubes of HEp-2 cell line $(0.2$ $\mathrm{ml} /$ tube) containing maintenance medium (Eagle's MEM with $\mathrm{NaHCO} 3$ $1.5 \mathrm{~g} / \mathrm{l}$, fetal bovine serum $2 \%$, HEPES $1 \mathrm{M}$ solution $1 \%$, L-Glutamine $200 \mathrm{mM}$ solution $2 \%$, penicillin, streptomycin and amphotericin B). For the growing of these cells the same medium was used, containing $10 \%$ of foetal bovine serum without amphotericin B. After inoculation, the tubes were kept at $35^{\circ} \mathrm{C}$ in incubator for two weeks. Each two or three days the cells were observed in order to visualize the cytopathogenic effect. The newborn mice ( 1 to 2 days of age) were inoculated with 0.02 $\mathrm{ml}$ through both cerebral and abdominal routes and observed during a period of 15 consecutive days.

Molecular technique: RT-PCR - This procedure was performed in
15 samples, at the Molecular Virology Unit of the Pasteur Institute in Paris, France. RNA was extracted from $100 \mu \mathrm{l}$ of CSF, according to the following steps: add of RNAzol B (guanidinium thiocyanate phenol solution) and chloroform, centrifugation, separation of aqueous fase, adding of isopropanol, centrifugation, discard of the supernatant, adding of ethanol $75 \%$, new centrifugation, vacuum drying, rehydration of the pellet, adding of $100 \%$ ethanol, $\mathrm{NaOH} 5 \mathrm{M}$ and mixture was kept at $-20{ }^{\circ} \mathrm{C}$ overnight. In the following day a new centrifugation was made, the supernatant was discarded, pellet was vacuum-dried and rehydrated thereafter with $10 \mu \mathrm{l}$ of sterile water and kept at $-20{ }^{\circ} \mathrm{C}$ until the synthetization of the cDNA.

The cDNA was synthesized using $3 \mu \mathrm{l}$ of extracted RNA and $17 \mu \mathrm{l}$ of the following mixture: $5 \mathrm{x}$ transcription buffer $4 \mu \mathrm{l}$, RNAsin $1 \mu \mathrm{l}$, dNTP $2 \mu \mathrm{l}$, primer dT15 $2 \mu \mathrm{l}$, RT-AMV $0.4 \mu \mathrm{l}$ and sterile water $7.6 \mu \mathrm{l}$. This mixture was incubated for 60 minutes at $42{ }^{\circ} \mathrm{C}$.

A semi-nested PCR test was performed using three different primers manufactured according to the instructions of Dr. Helena Kopecka (Pasteur Institute, Paris) based on the conserved region of the Polio 1 genome and named primer 2 (5' CAAGCACUUCUGUUUCCCCGG 3' nucleotides 163-182), primer 3 (5' UGGCUGCUUAUGGUGACAAU 3' nucleotides 575-595) and primer 10 (5' CGACUACUUUGGGUGUCCGU 3' nucleotides 537-556). The mix consisted of: $10 \mathrm{x}$ Taq buffer, $10 \mu \mathrm{l} ; \mathrm{MgCl}_{2}$ $(25 \mathrm{mM}), 6 \mu \mathrm{l}$; dNTP $(2 \mathrm{mM}), 10 \mu \mathrm{l}$; primer $2,1 \mu \mathrm{l}$; primer $3,1 \mu \mathrm{l}$; Taq polymerase, $0.5 \mu \mathrm{l}$; and sterile water, $66.5 \mu \mathrm{l}$. This mixture was used in the first and second PCR except for primer 3 which in the second PCR was substituted for primer 10. A thermocycler Cyclogene was programmed to develop 30 cycles, as follows: $50^{\circ} \mathrm{C}, 30$ "; $72{ }^{\circ} \mathrm{C}, 30$ " and $94{ }^{\circ} \mathrm{C}, 30$ ”. The final product was then submitted to $1 \%$ agarose gel electrophoresis and stained with ethidium bromide.

\section{RESULTS}

All 81 samples were negative for viruses by the routine cell culture and mouse inoculation procedures. Only 15 samples were available for RT-PCR testing. Table 1 shows the results of the 15 cases studied by RTPCR. The ages of the 14 patients whose age information was available ranged from 1 to 55 years (average 15.7). Nine patients were female and 6 male. All samples yielded negative results in cell culture and newborn mouse inoculation, while $9(60.0 \%)$ were PCR-positive (6 with motor disorders and 3 with aseptic meningitis cases). Of the six cases of motor disorders, two were diagnosed as GBS in adolescents (12 y and 14y).

The 6 PCR-negative samples corresponded to three cases of AM and three of motor disorder. Of 6 cases of AM, RT-PCR was positive in 3 and of 9 cases of motor disorder, 6 were positive by RT-PCR. It was not possible to get information about the onset of disease, a date that would be relevant to the analysis of these cases. Figure 1 shows the results of RT-PCR for the $15 \mathrm{CSF}$ samples. All positive samples display bands with the expected size.

\section{DISCUSSION}

While the detection of enteroviral genome in specimens obtained from cases of AM is reported in several studies ${ }^{2,3,5,11,14}$, there are few molecular analyses focusing on motor disorders caused by non polio enteroviruses. Studies performed by RIDING et al. ${ }^{11}$ showed that of 366 samples tested, $27 \%$ were positive by nested enteroviral PCR, whereas 
Table 1

Viral isolation and PCR results in 15 CSF samples from patients from Pará, Brasil

\begin{tabular}{|c|c|c|c|c|c|c|c|}
\hline \multirow[t]{2}{*}{ No. } & \multirow[t]{2}{*}{ Name } & \multirow[t]{2}{*}{ Age/Sex } & \multirow[t]{2}{*}{ Diagnostic } & \multirow[t]{2}{*}{ Sample date } & \multicolumn{3}{|c|}{ R E S U L T S } \\
\hline & & & & & $\mathrm{TC}$ & NM & PCR \\
\hline 01 & R.F.C.A & 55 y $\mathrm{F}$ & Aseptic meningitis & $03 / 28 / 95$ & Neg & $\mathrm{Neg}$ & Neg \\
\hline 02 & E.S.B.L. & 11 y $\mathrm{M}$ & Motor deficiency & $04 / 13 / 95$ & Neg & $\mathrm{Neg}$ & Neg \\
\hline 03 & R.A.M & 20 y M & Motor deficiency & $04 / 18 / 95$ & $\mathrm{Neg}$ & Neg & $\mathrm{Neg}$ \\
\hline 04 & N.S.S.A & 09 y F & Aseptic meningitis & $05 / 12 / 95$ & Neg & Neg & Pos \\
\hline 05 & K.K & 14 y $\mathrm{M}$ & Aseptic meningitis & $05 / 30 / 95$ & Neg & Neg & $\mathrm{Neg}$ \\
\hline 06 & B.S.S.R & 24 y F & Motor deficiency & $05 / 31 / 95$ & Neg & $\mathrm{Neg}$ & Pos \\
\hline 07 & L.D.C & 12 y F & Guillain Barré syndrome & 06/07/95 & $\mathrm{Neg}$ & $\mathrm{Neg}$ & Pos \\
\hline 08 & A.M.R & 22 у M & Aseptic meningitis & $07 / 04 / 95$ & $\mathrm{Neg}$ & $\mathrm{Neg}$ & Pos \\
\hline 09 & G.O & 02 y NA & Aseptic meningitis & 07/06/95 & Neg & Neg & $\mathrm{Neg}$ \\
\hline 10 & J.L.N.S. & 01 y F & Motor deficiency & $07 / 27 / 95$ & Neg & Neg & Pos \\
\hline 11 & S.V.R & 03 y F & Motor deficiency & 08/04/95 & Neg & $\mathrm{Neg}$ & Pos \\
\hline 12 & H.N.L.L & NA $F$ & Motor deficiency & 08/30/95 & $\mathrm{Neg}$ & $\mathrm{Neg}$ & Neg \\
\hline 13 & M.J.R.S & 14 y $\mathrm{M}$ & Guillain Barré syndrome & 09/01/95 & Neg & $\mathrm{Neg}$ & Pos \\
\hline 14 & M.A.R & 15 y F & Motor deficiency & $10 / 13 / 95$ & $\mathrm{Neg}$ & $\mathrm{Neg}$ & Pos \\
\hline 15 & B.S.A.R & 19 у M & Aseptic meningitis & $01 / 17 / 96$ & Neg & $\mathrm{Neg}$ & Pos \\
\hline
\end{tabular}

$\mathrm{TC}=$ tissue culture $\mathrm{NM}=$ newborn mouse $\mathrm{NA}=$ not available

\section{8}

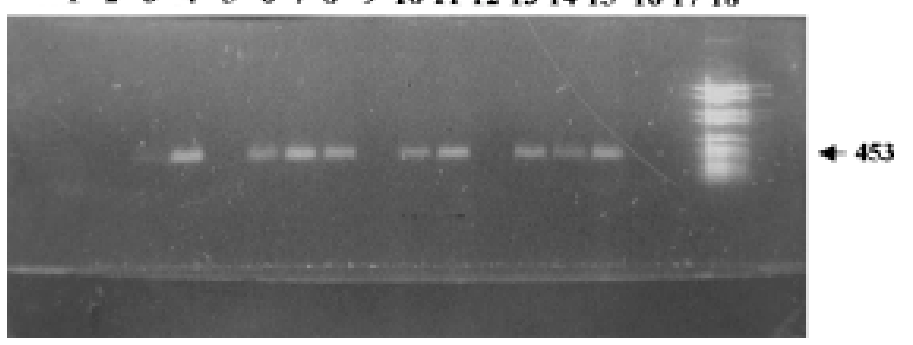

Fig. 1 - RT-PCR with CSF samples from cases of aseptic meningitis and motor deficiency in Belém-Pará-Brazil

Lanes 4, 8 and 15: aseptic meningitis cases; Lanes 6,7,10,11, 13 and 14: motor deficiency cases; Lane 18: molecular weight markers.

only $6 \%$ were positive by virus isolation. Enterovirus RNA was detected more commonly in stool samples (38\% positive) but less frequently from throat swabs and CSF ( $26 \%$ and $25 \%$ positivity, respectively). THORÉN $\&$ WIDELL ${ }^{16}$ reported that, in CSF samples from 27 patients, enteroviral RNA was detected in 15 , whereas only 6 patients were positive as based on virus isolation. Considering the positivity rate using PCR, our results were similar to those, since $60 \%(9 / 15)$ of our samples were positive by PCR and none were positive by virus isolation. On the other hand, they differ from results reported by those authors because we did not find any positive results in cell culture, which is not common. In fact the failure rate in recovering EV by tissue culture from patients with apparent EV meningitis is: $25 \%$ to $30 \%{ }^{13}$. It is likely that negative results through attempts of virus isolation, in our study, could be explained by the methodology used, which differed from that used in the other studies. Our procedures included replacement of the growth medium by the maintenance medium and then inoculation of the sample. In the other studies, the growth medium was harvested, the sample was inoculated and, after at least 30 minutes, the maintenance medium was added.

Although we have analyzed a limited number of patients, our results are of potential importance since they highlights the possible role of enterovirus in the aetiology of motor deficiency and GBS in our region. Further studies are needed, however, in order to better understand the epidemiology of these enterovirus-related neurological disorders in our region.

\section{RESUMO}

\section{Pesquisa de enterovírus em casos de meningite assética e síndrome de deficiência motora em Belém, Pará, Brasil}

Amostras de líquido céfalo raquidiano colhidas de 81casos (principalmente meningite asséptica e deficiência motora) foram recebidas na Seção de Virologia do Instituto Evandro Chagas em Belém, Pará no período de janeiro de 1995 a janeiro de 1996, para investigação etiológica. Todas as amostras foram inoculadas em células HEp-2 e em camundongos recém nascidos, com resultados negativos. A probabilidade de se isolar vírus por esse método é reduzida devido à baixa concentração de partículas virais nesses espécimes. Com o objetivo de se obter mais informações sobre a etiologia desses casos, um grupo de 15 amostras, foram testadas usando a reação em cadeia de polimerase com transcrição reversa uma técnica mais sensível que o isolamento. Foram usados "iniciadores" específicos direcionados à região de sequiências conservadas dos enterovírus, considerando que este grupo de vírus é mais freqüientemente relacionado a desordens neurológicas. A idade dos pacientes variou de 1 a 55 anos, e quase todos viviam em Belém, Pará, norte do Brasil. Das 15 amostras analisadas, nove $(60 \%)$ foram positivas - $6(66,6 \%)$ relacionadas a deficiência motora e $3(33,3 \%)$ a meningite asséptica. Esses resultados, indicam a importância de investigar enterovírus como etiologia dessas síndromes. 


\section{REFERENCES}

1. BERLIN, L.E.; RORABAUGH, M.L.; HELDRICH, F. et al. - Aseptic meningitis in infants < 2 years of age: diagnosis, and etiology. J. infect. Dis., 168: 888-892, 1993.

2. GLIMAKER, M. - Enteroviral meningitis. Diagnostic methods and aspects on the distinction from bacterial meningitis. Scand. J. infect. Dis., 85(suppl.): 1-64, 1992.

3. GLIMAKER, M.; JOHANSSON, B.; OLCÉN, P.; EHRNST, A. \& FORSGREN, M. Detection of enteroviral RNA by polymerase chain reaction in cerebrospinal fluid from patients with aseptic meningitis. Scand. J. infect. Dis., 25: 547-557, 1993.

4. GODOY, C.V.F.; CARVALHO, R.P.S.; KIRCHNER, E.; PEREIRA, O.A.C. \& PUPO, A.A. - Síndrome de meningite asséptica. Esclarecimento etiológico de alguns casos na cidade de São Paulo. Considerações clínico-laboratoriais. Rev. Inst. Med. trop. S. Paulo, 9: 213-221, 1967.

5. GORGIEVSKI-HRISOHO, M.; SCHUMACHER, J.D.; VILIMONOVIC, N.; GERMANN, D. \& MALTTER, L. - Detection by PCR of enteroviruses in cerebrospinal fluid during a summer outbreak of aseptic meningitis in Switzerland. J. clin. Microbiol., 36: 2408-2412, 1998.

6. HART, D.E.; ROJAS, L.A.; ROSARIO, J.A.; RECALDE, H. \& ROMAN, G.C. Childhood Guillain-Barré syndrome in Paraguay, 1990 to 1991. Ann. Neurol., 36: 859-863, 1994.

7. JARVIS, W.R. \& TUCKER, G. - Echovirus type 7 meningitis in young children. Amer. J. Dis. Child, 135: 1009-1012, 1981.

8. KINNUNEN, E.; HOVI, T.; STENVIK, M. et al. - Localized outbreak of enteroviral meningitis in adults. Acta neurol. scand., 75: 346-351, 1987.
9. MARIER, R.; RODRÍGUEZ, W.; CHLOUPEK, R.J. et al. - Coxsackievirus B5 infection and aseptic meningitis in neonates children. Amer. J. Dis. Child, 129: 321-325, 1975.

10. MELNICK, J.L. - Enteroviruses. In: FIELDS, B.N.; KNIPE, D. M. \& HOWLEY, P.M., ed. Virology. 2. ed. New York, Raven Press, 1990. v. 1, p. 549-605.

11. RIDING, M.H.; STEWART, J.; CLEMENTS, G.B. \& GALBRAITH, D.N. - Enteroviral polymerase chain reaction in the investigation of aseptic meningitis. J. med. Virol., 50: 204-206, 1996

12. ROPPER, A.H. - The Guillain-Barré syndrome. Review article. New Engl. J. Med., 326: $1130-1136,1992$

13. ROTBART, H.A. - Diagnosis of enteroviral meningitis with the polymerase chain reaction J. Pediat., 117: 85-89, 1990.

14. ROTBART, H.A.; AHMED, A.; HICKEY, S. et al. - Diagnosis of enterovirus infection by polymerase chain reaction of multiple specimen types. Pediat. infect. Dis. J., 16: 409-411, 1997 .

15. TAKIMOTO, S.; TANAKA, H.; GOMES, L.F.S. et al. - Preliminar characterization of a new virus isolated from spinal fluid of patients with meningitis in São Paulo, Brazil. Rev. Inst. Med. trop. S. Paulo, 32: 162-167, 1990.

16. THORÉN, A. \& WIDELL, A. - PCR for the diagnosis of enteroviral meningitis. Scand. J. infect. Dis., 26: 249-254, 1994.

17. URANO, T.; KAWASE, T.; KODAIRA, K. et al.- Guillain-Barré syndrome associated with ECHO virus type 7 infections. Pediatrics, 45: 294-295, 1970.

Received: 18 October 2000

Accepted: 02 October 2001 